\title{
Screening of Blackberry and Raspberry Cultivars for Susceptibility to Fire Blight Disease in Turkey
}

\author{
Kubilay Kurtulus Bastas ${ }^{1,3}$ \\ Department of Plant Protection, Faculty of Agriculture, Selcuk University \\ 42031, Campus, Konya, Turkey
}

\author{
Fikrettin Sahin ${ }^{2}$ \\ Department of Genetics and Bioengineering, Faculty of Engineering and \\ Architecture, Yeditepe University, 34755 Istanbul, Turkey
}

Additional index words. raspberry, blackberry, cultivar, resistance, Erwinia amylovora

\begin{abstract}
Fire blight is the most destructive bacterial disease of rosaceous plants containing berry fruits. The present study was conducted to determine host resistance among the extensively grown raspberry cultivars (Willamette, Rubin ve Aksu Red, Heritage, and Royalty) and blackberry cultivars (Bursa-1, Bursa-2, Bursa-3, Chester, Loch Ness, and Jumbo) to Erwinia amylovora, which is the causal agent of the fire blight disease. In the greenhouse and field experiments, the plants were inoculated with two virulent strains of $E$. amylovora to evaluate whether cultivar-strain interactions exist. Disease index $(\%)$ and disease severity $(\%)$ were determined regarding diseased plant symptoms and classified into four susceptibility groups (HR, MR, S, and HS). Raspberry cultivar Willamette and blackberry cultivar Bursa-1 appeared to be highly susceptible with average $50 \%$ disease severity ratings. One of the raspberry cv., Royalty, was moderately resistant with an average $25 \%$ disease severity rating. This is the first study determining resistance reactions of native and common blackberry and raspberry varieties against fire blight in Turkey. As the cultivation of berries expands to new regions and larger acreages, a serious outbreak of fire blight may be potentially much more destructive in the future. Therefore, phytosanitary measures are needed to prevent any further spread of the bacterium to new blackberry- and raspberry-growing areas. The study will serve as an initial guide for growers and breeders for their appropriate raspberry and blackberry selections in Turkey.
\end{abstract}

Blackberry (Rubus fruticosus) and raspberry ( $R$. idaeus), belonging to genus Rubus, family Rosaceae, are widespread perennial shrubs. They are known to contain naturally occurring polyphenol antioxidants that can regulate certain beneficial metabolic processes in mammals. Also, they have a high abundance of healthy antioxidants and nutrients such as anthocyanins, salicylic acid, ellagic acid, pectin, $\mathrm{B}$ and $\mathrm{C}$ vitamins, and fiber. In herbal medicine, they are reputed to be effective in regulating many health problems (Ahn et al., 1996; Carvalho et al., 2013; Heinonen, 2007; Sellappan et al., 2002).

The berries have been grown in many parts of world including the United States and Europe. Turkey is one of the leading countries in berry cultivation and especially blackberry has gained considerable importance during recent years. Consumption of wild

\footnotetext{
Received for publication 8 Aug. 2014. Accepted for publication 17 Oct. 2014.

This study was funded by Selcuk University Scientific Research Project's coordinators.

${ }^{1}$ Assistant Professor, Research Leader, and Lecturer.

${ }^{2}$ Professor and Research Leader.

${ }^{3}$ To whom reprint requests should be addressed; e-mailkbastas@selcuk.edu.tr.
}

berries used to be popular, especially in the Black Sea region; however, in recent years, cultivated berries are grown in large areas as a result of breeding studies. The Marmara and Black Sea regions are the most environmentally desirable areas for raspberry production (Onur, 1996). Adaptation performance of blackberry cultivars imported from the United States has shown variable performance in 16 regions of Turkey for 9 years (Agaoglu, 2003). Ipek et al. (2009) investigated genetic diversity of some blackberry cultivars (Arapaho, Black Satin, Bursa-1, Bursa-2, Bursa-3, Chester, Dirckson Thornless, Jumbo, Navaho and Loch Ness, and Boysenberry) using amplified fragment length polymorphic markers. In addition, 12 different raspberry cultivars: Summit, Heritage, Williamette, Meeker, Tulameen, Cola II, Newburgh, Canby, Rubin, Aksu Red, Bursa Dwarf, and Yalova-I, were tested for plant adaptation studies (Barut, 2000).

Fire blight, caused by the bacterium Erwinia amylovora (Burr.) Winslow et al., is a disease that affects many Rosaceous species with apple (Malus sp.) and pear (Pyrus $\mathrm{sp}$.) being of the greatest economic significance (Bonn and van der Zwet, 2000). The most striking symptom is blackened cane tips, which bend over and die, resulting in a "shepherd's crook" appearance. As the disease progresses down the cane, the veins of the leaf and portions of the leaf surrounding the midvein turn black. Entire leaves may wither and die. Typically, discoloration and dieback are limited to succulent young growth. Infected peduncles turn black and the young developing berries become brown, dry, and very hard. Entire fruit clusters may be infected, but generally a few berries in each cluster remain healthy. Losses result from berry necrosis and from tip dieback of primocanes (Schilder, 2007).

The disease was first observed in the late $1800 \mathrm{~s}$ in raspberry (Ries and Otterbacher, 1977). Fire blight outbreaks are less common in Rubus species but can reach economically damaging levels under certain conditions (Braun et al., 1999). Lehman demonstrated that bacteria isolated from raspberry with fire blight symptoms infected wound-inoculated Rubus spp. canes, but not apple shoots, and that E. amylovora isolated from apple twigs did not infect raspberry canes (Lehman, 1933).

Management strategies in apple and pear have focused on timely applications of copper, antibiotics such as streptomycin, and removal of inoculum sources by pruning and the use of resistant cultivars (Beer, 1990). Of these options, cultivar resistance is the most desirable for its cost-effectiveness and longterm stability. Development of resistant cultivars requires advanced planning in breeding programs to incorporate and maintain a diverse range of resistance genes in parental lines, but little is known about raspberry and blackberry resistance to fire blight.

In Turkey, fire blight was observed the first time on blackberry (Rubus fruticosus cv. Chester) during 2008 and 2009 (Bastas and Sahin, 2012). Because of the sporadic nature of fire blight in Rubus, genetic resistance may be a better option for control than preventive sprays or predictive models. The purpose of this study was to identify and quantify resistance in currently available commercial raspberry and blackberry cultivars to assist growers in making appropriate selections for their disease situation and to aid breeders in the selection of parental plant material for breeding purposes.

\section{Materials and Methods}

Plant materials and growing conditions. The studies were carried out on a total of 11 blackberry cultivars (Chester Thornless, Jumbo, Loch Ness, Bursa-1, Bursa-2, and Bursa-3) and raspberry cultivars (Heritage, Williamette, Rubin, Aksu Red, and Royalty) grown widely in Turkey. The test plants were propagated by digging suckers and were selected among 3-year-old saplings showing uniform growth. Twenty saplings from each cultivar (10 plants for each Ea strain) were transplanted into plastic pots of $20 \mathrm{~cm}$ diameter filled with $4 \mathrm{~kg}$ of soil, and they were grown for $20 \mathrm{~d}$ at $25 \pm 2{ }^{\circ} \mathrm{C}, 60 \%$ to $75 \%$ relative humidity $(\mathrm{RH})$, and under 12,000 to 14,000 Lux from tungsten-filament lamps for a 16-h photoperiod. After transplantation, the plants were fertilized once a week (each pot) 
with $15 \mathrm{~g}$ ammonium sulfate, $15 \mathrm{~g}$ diammonium phosphate, $15 \mathrm{~g}$ potassium sulfate, and $30 \mathrm{~mL}$ of a liquid fertilizer having $0.05 \%$ manganese, copper, zinc, boron, and molybdenum (Kacar and Katkat, 1999). The soil used in the experiments is characterized by $1.9 \%$ total soil organic matter, $0.08 \%$ total salts, $63 \%$ soil saturation percentage, and $8.1 \%$ lime $\left(\mathrm{CaCO}_{3}\right)$ with soil $\mathrm{pH}$ of 7.8 in distilled water $(1.5 \mathrm{v} / \mathrm{v})$. The plots were trickle-irrigated as needed. In addition, sulfur dust (Thiovit, 80\% microlized sulfur; Syngenta) was applied once (4 g. $\mathrm{L}^{-1}$ water) for powdery mildew and mite control.

Twenty-five days later after the transplantation, seven of 14 potted plants from each cultivar were placed on the ground $1 \mathrm{~m}$ apart at the experiment field of Selcuk University, Konya province, and were watered regularly throughout the growing season.

Erwinia amylovora strains and media used. A strain of E. amylovora (Eab14) isolated from blackberry and a virulent strain EapK from apple (Selcuk University Faculty of Agriculture Department of Plant Protection Bacterial Culture Collection) were used in the experiments. The strains were obtained from the preselected strains causing $\approx 80 \%$ to $90 \%$ disease severity on the basis of the virulence test reported by Norelli et al. (1984). The virulence was tested on cv. Williams pear seedlings. They were verified as E. amylovora by streaking on Crosse and Goodman (CG) media (Crosse and Goodman, 1973), where it displayed typical colony morphology. The bacterium was grown in a liquid culture of 523 medium (Kado and Heskett, 1970) and stored at $-20{ }^{\circ} \mathrm{C}$ in solution with $30 \%$ glycerol. Two days before inoculations, frozen stock was streaked on plates of CG medium and incubated at $28^{\circ} \mathrm{C}$.

Plant inoculation. All plants were kept at $85 \%$ to $90 \%$ RH supported by misting, before the inoculations. Bacterial suspensions were prepared from growing colonies on $\mathrm{CG}$ at $28{ }^{\circ} \mathrm{C}$ and were diluted in sterile distilled water (SDW) to give an absorbance of 0.15 at $660 \mathrm{~nm}$. This represented $10^{8}$ colony-forming units $(\mathrm{cfu}) / \mathrm{mL}$ based on viable plate counts. Inoculum was maintained on ice during inoculation of the plants. Inoculation of the youngest two to three leaflets at the actively growing shoot tips was attempted by cutting through them with a scissor that had been dipped into $10^{8} \mathrm{cfu} / \mathrm{mL}^{1}$ EapK and Eab14 strains of $E$. amylovora. The treated shoots were labeled with flagging tape for evaluation purposes (Norelli et al., 1984; Zeller and Meyer, 1975). Additionally, five plants each of blackberry and raspberry cultivars were inoculated with sterile water as controls. All seedlings received an additional misting immediately after inoculation and they were covered with a polyethylene bag for $24 \mathrm{~h}$ to maintain high humidity. To enhance disease development, the greenhouse was maintained at $24 \pm 2{ }^{\circ} \mathrm{C}$ and kept shaded using shadecloth. Also, the inoculated plants were misted with water four times at equal intervals to maintain humidity.

Reisolation of E. amylovora from berries and identification. After ratings were taken from the inoculated plants, diseased and symptomless plants were randomly selected and sampled at the point of inoculation. The samples were surface-disinfected by immersion in $1 \%$ sodium hypochlorite for $3 \mathrm{~min}$, cut into small segments, and soaked $30 \mathrm{~min}$ in SDW. The liquid was then streaked on CG media. $E$. amylovora was identified by colony morphology, biochemical and physiological tests, and using the species-specific primers set, A/B (A: 5' CGGTTTTTAACGCTGGG $3^{\prime}$ and B: 5' GGGCAAATACTCGGATT $3^{\prime}$ ) by polymerase chain reaction (PCR) assay to generate a 1-kb DNA fragment based Koch postulates and compared with E. amylovora strain NCPPB 2791 as a positive control (Bereswill et al., 1992; Klement et al., 1990; Lelliott and Stead, 1987; Llop et al., 1999; Momol et al., 1997; Schaad et al., 2001).

Evaluation of disease index and severity. The experiment was set up in a completely randomized block design with five replicates. A single replicate was a mean from three shoots on one sapling (Duzgunes et al., 1987).

Seven days after bacterial inoculation, the plants were rated on a scale of 0 to 10 as given subsequently and Figure 1 for disease index $(\%)$ :

$0=$ no visible symptom;

$1=$ slightly browning of the main leaf vein

from the point of cutting ( 3 to $5 \mathrm{~mm}$ );

2 = browning of the main leaf vein from

the point of cutting (less than $5 \mathrm{~mm}$ );

3 = browning of all of the main leaf vein from the point of cutting;

4 = browning and/or necrosis (quarter of the leaf) of the main and side leaves vein from the point of cutting;

$5=$ browning and/or necrosis (half of the leaf) of the main and side leaves vein from the point of cutting;

6 = browning and/or necrosis (threefourths of the leaf) of the main and side leaves vein from the point of cutting.
7 = browning of the whole leaf and/or progressing of the necrosis to the leaf petiole; $8=$ browning of the whole leaf and the necrosis of the leaf petiole;

$9=$ browning of the whole leaf and shoot infection $(0.1$ to $2 \mathrm{~cm})$; and

$10=$ necrosis in whole veins of leaves and shoot infection (2.1 cm or more).

\section{Disease Index (\%)}

$$
\begin{aligned}
& =\sum\left(\frac{\left(d \ln \times s c_{1}\right)+\ldots \ldots+\left(d \ln \times s c_{10}\right)}{\left(t \ln \times s c_{10}\right)}\right) \\
& \times 100
\end{aligned}
$$

where $d l n=$ diseased leaf number; $s c=$ symptom class; and $t \ln =$ total leaf number.

The length of visible fire blight lesions and of the current season's shoot growth was recorded after all lesions had ceased to extend, as indicated by the formation of a determinate margin between diseased and healthy tissues. Disease severity (DS, \%) was calculated by the following equation;

$$
D S(\%)=(a / b) \times 100
$$

where $a$ is the length of the blighted part of the shoot $(\mathrm{cm})$; and $b$ is the whole length of the shoot $(\mathrm{cm})$ (Aldwinckle et al., 2002; Fernando and Jones, 1999).

Van der Zwet and Keil (1979) developed an estimate if the severity of damage and percent blight resistance arranged as four classes. In this study, evaluation of classification was modified and used percent disease severities (Table 1).

Data analysis. Data were subjected to analysis of variance, and differences between means were compared by the MINITAB Version 14 (State College, PA) statistical program. The means (expressed as percent disease) were used to determine significant treatment differences. Data were analyzed using MSTAT software [Michigan State University (MSU), East Lansing, MI] and the differences between treatments were determined by the least significant difference new multiple range test (MSU, 1986) at $P<0.01$ and $P<0.05$.

Table 1. Resistance classes according to disease severities (\%) for fire blight.

\begin{tabular}{lc}
\hline Resistance class & $\begin{array}{c}\text { Disease severity } \\
\text { (DS) (\%) }\end{array}$ \\
\hline Highly resistant (HR) & $0-6$ \\
Moderately resistant (MR) & $7-25$ \\
Susceptible (S) & $26-50$ \\
Highly susceptible (HS) & $51-100$ \\
\hline
\end{tabular}

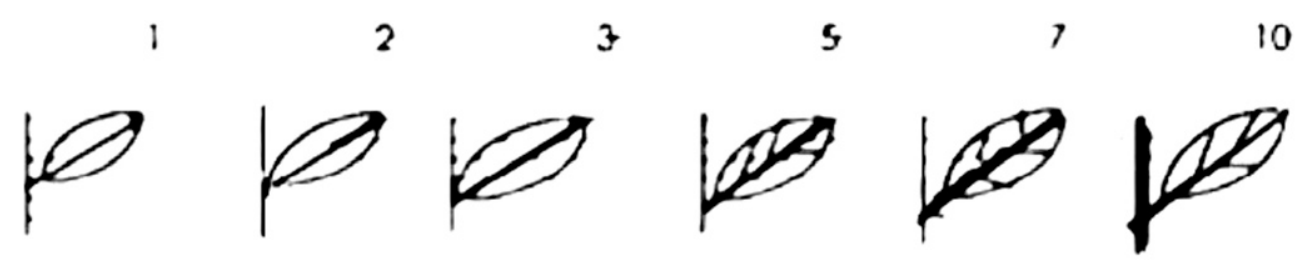

Fig. 1. Leaf symptom scale of fire blight disease for evaluation of disease index. 


\section{Results and Discussion}

Fire blight disease has been a serious problem in rosaceous plants since it was first reported in 1793 (Van der Zwet and Keil, 1979); however, it has received less attention on berries than apple and pear, whereas the disease on Rubus spp. can be as destructive affecting the current and the next year's crop (Braun and Hildebrand, 2006).

Cultivar resistance is the most desirable within combat strategies to fire blight (Beer, 1990). Although many evaluations of fire blight resistance in apple and pear genotypes have been conducted, little work has been done with berries. Braun et al. (2004), Braun et al. (1999), Folsom (1947), Heimann and Jeffers (1990), Lehman (1933), Folsom, Ries (1997), Starr et al. (1951), and Stewart et al. (2005) noted that some raspberry and blackberry cultivars appeared to differ considerably in their level of resistance against $E$. amylovora. This study is the first to quantify levels of fire blight resistance in some native and common raspberry and blackberry cultivars in Turkey.

Fire blight symptoms on raspberry and blackberry were similar to those that occur on some fruits. On leaves, symptoms began with the blackening of veins that spreads rapidly from the petiole and midrib to the leaf margins. Leaves turned brown and wilted. Symptoms of water soaking appear on succulent primocane tips and laterals of floricanes followed by rapid blackening, wilting, and eventual collapse of tissues. Our inoculation method resulted in typical fire blight symptoms, which began to appear 3 to $5 \mathrm{~d}$ after inoculation. On some cultivars, blackened areas around the wound sites were the first visible symptoms, which subsequently spread to veins of the nearest leaf (Fig. 3). As the lesions expanded, droplets of bacterial ooze developed and the canes wilted. Lesions stopped expanding after 25 to $30 \mathrm{~d}$ of incubation.

Analysis of variance indicated that the plant cultivars, strains of E. amylovora, and conditions of greenhouse and field experiments were the primary sources of variance in the study; however, there were no significant interaction observed between cultivar $x$ bacterial strains $\times$ greenhouse or field conditions (Table 2). In terms of the percent disease severity, significant differences were noted among the cultivars evaluated, indicating a wide range of resistances to the fire blight pathogen. Rubus idaeus $\mathrm{cv}$. Willamette and $R$. fruticosus cv. Bursa-1 appeared highly susceptible with average $50 \%$ disease severity ratings. 'Royalty' was the most resistant cultivar within raspberry cultivars (Table 2; Fig. 2). Raspberry cultivars, Rubin, Aksu Red, and Heritage, and blackberry cultivars Bursa-2, Chester, Loch Ness, and Jumbo of all cultivars showed reaction classified as susceptible to the disease with an average rating between $51 \%$ and $28 \%$ (Table 2).

Percent disease indices determined parallel results to disease severities to each other, and there were numerical small differences between cultivars, bacterial strains, and greenhouse or field conditions (Table 2).

During the experiments, 'Bursa-3' was excluded as a result of it being damaged. Blackberry and raspberry cultivars had statistically significant differences between the cultivars at $P<0.01$ (Tables 3 and 4). No symptoms were observed on any of the control plants.

Bacteria were consistently isolated from the diseased tissues and identified on the basis of biochemical, physiological, and molecular tests (Bereswill et al., 1992; Schaad et al., 2001). The isolated bacterial strains were Gram-negative, rod-shaped, mucoid, fermentative, yellow-orange on Murashige and Skoog medium, positive for levan formation and acetoin production, no growth at $36{ }^{\circ} \mathrm{C}$, positive for gelatin hydrolysis, and

Table 2. Disease severity (\%), disease index (\%), and resistance class of various raspberry and blackberry cultivars against fire blight disease in greenhouse and field using EapK and Eab14 strains of Erwinia amylovora.

\begin{tabular}{|c|c|c|c|c|c|c|c|}
\hline & & \multicolumn{3}{|c|}{ Erwinia amylovora strain EapK ${ }^{z}$} & \multicolumn{3}{|c|}{ Erwinia amylovora strain Eab14 } \\
\hline & & $\begin{array}{c}\text { DS (\%) in } \\
\text { greenhouse/resistance } \\
\text { class }\end{array}$ & $\begin{array}{c}\text { DS (\%) in } \\
\text { field/resistance } \\
\text { class }\end{array}$ & DI $(\%)$ & $\begin{array}{c}\text { DS (\%) in } \\
\text { greenhouse/resistance } \\
\text { class }\end{array}$ & $\begin{array}{c}\text { DS (\%) in } \\
\text { field/resistance } \\
\text { class }\end{array}$ & DI $(\%)$ \\
\hline & Aksu Red & $42.99 \pm 5.2 \mathrm{~S}$ & $41.85 \pm 3.6 \mathrm{~S}$ & 36.1 & $46.12 \pm 6.0 \mathrm{~S}$ & $43.21 \pm 2.6 \mathrm{~S}$ & 28.2 \\
\hline & Heritage & $41.92 \pm 1.7 \mathrm{~S}$ & $36.73 \pm 3.3 \mathrm{~S}$ & 34.9 & $42.95 \pm 4.1 \mathrm{~S}$ & $40.15 \pm 2.1 \mathrm{~S}$ & 28.6 \\
\hline & Royalty & $23.20 \pm 1.4 \mathrm{MR}^{3}$ & $19.87 \pm 1.7 \mathrm{MR}$ & 26.8 & $25.00 \pm 4.2 \mathrm{MR}$ & $23.57 \pm 3.3 \mathrm{MR}$ & 24.4 \\
\hline & Bursa 2 & $45.01 \pm 3.0 \mathrm{~S}$ & $40.67 \pm 2.5 \mathrm{~S}$ & 34.7 & $47.80 \pm 7.8 \mathrm{~S}$ & $42.12 \pm 1.4 \mathrm{~S}$ & 35.8 \\
\hline & Bursa 3 & ND & ND & ND & ND & ND & ND \\
\hline & Chester & $38.73 \pm 1.0 \mathrm{~S}$ & $34.70 \pm 4.3 \mathrm{~S}$ & 33.9 & $43.75 \pm 5.6 \mathrm{~S}$ & $39.35 \pm 3.5 \mathrm{~S}$ & 35.6 \\
\hline & Loch Ness & $32.94 \pm 1.2 \mathrm{~S}$ & $28.77 \pm 1.6 \mathrm{~S}$ & 30.4 & $33.92 \pm 1.7 \mathrm{~S}$ & $32.24 \pm 1.9 \mathrm{~S}$ & 31.3 \\
\hline & Jumbo & $31.09 \pm 1.9 \mathrm{~S}$ & $28.45 \pm 1.0 \mathrm{~S}$ & 29.6 & $31.84 \pm 2.9 \mathrm{~S}$ & $31.15 \pm 1.0 \mathrm{~S}$ & 31.8 \\
\hline
\end{tabular}

${ }^{\mathrm{z}}$ Cultivars are ranked from least resistant to most resistant.

yplants were inoculated with two strains of Erwinia amylovora. Lesion length was measured on the seventh day after inoculation for disease index (\%) and $\approx 1$ month later for disease severity (\%).

$\mathrm{DS}=$ disease severity; $\mathrm{DI}=$ disease index; $\mathrm{ND}$ = not determined; HS = highly susceptible; $\mathrm{S}=$ susceptible; $\mathrm{MR}=$ moderately resistant.
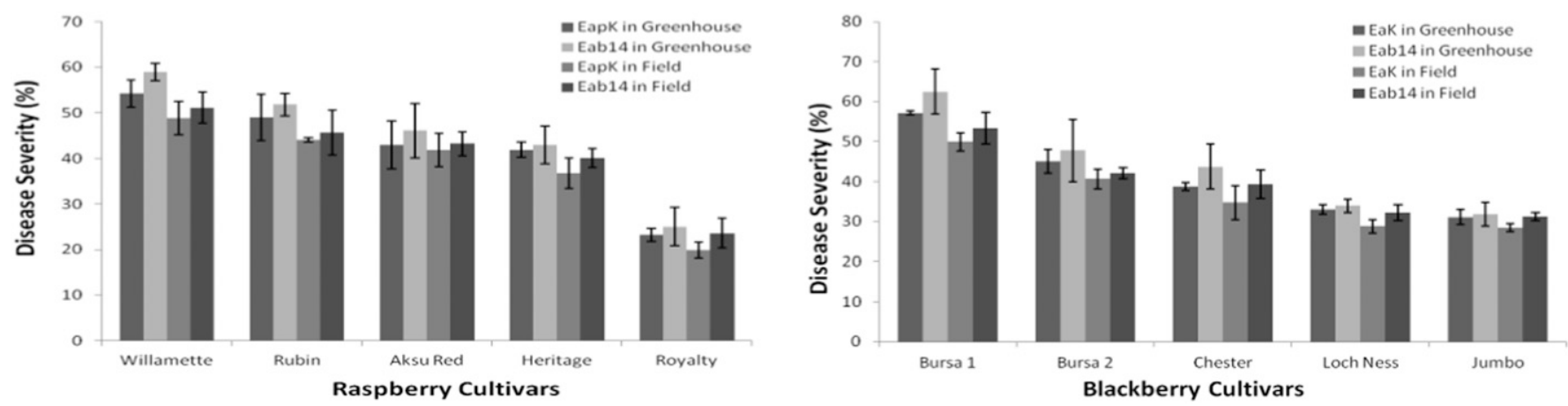

Fig. 2. Disease severity (\%), disease index (\%), and resistance class of various raspberry and blackberry cultivars against fire blight disease in greenhouse and field using EapK and Eab14 strains of Erwinia amylovora. 
negative for esculin hydrolysis, indole, urease, catalase, oxidase, arginine dehydrolase, reduction of nitrate, and acid production from lactose and inositol. All strains were identified as Erwinia amylovora using the species-specific primers set; A/B (2) amplified a 1-kb DNA fragment in PCR (Fig. 3).

Braun et al. (2004) and Ries and Otterbacher (1977) confirmed varietal differences in resistance to fire blight among raspberry cultivars. Although Ries and Otterbacher (1977) found several resistant raspberry cultivars, including 'Fall Red' and 'Heritage', none of the nine blackberry cultivars included in their study demonstrated any resistance to the pathogen. Braun et al. (1999) showed that some red raspberry seedlings with the same parents appeared to differ considerably in their level of resistance, and those certain cultivars appeared frequently in the parents of resistant selections. Stewart et al. (2005) studied blackberries in both seedling populations and clonally propagated plants ('Apache', 'Arapaho', 'Chester Thornless', 'Illini Hardy', 'Navaho', 'Triple Crown', 'Prime-Jim', 'Chickasaw', 'Kiowa', 'Ouachita', 'Shawnee', 'A-2046', 'A-2095', 'A-2200', 'APF-19', 'APF-37', 'APF-41') and 'Kiowa' and a breeding selection, 'A-2095', were determined as the most resistant against fire blight. In our field trials, cv. Heritage gave less numerical disease severity values than the other susceptible cultivars, 'Rubin', and 'Aksu Red'. The data in the present study suggested that raspberry cultivar Willamette and blackberry cultivar Bursa- 1 are the most susceptible ones among the other cultivars grown in central Anatolia.

None of the cultivars tested in our study showed immune or symptomless reaction to fire blight. The levels of resistance in raspberry and blackberry cultivars against fire blight were determined based on the evaluation of disease development on vegetative parts without flower interaction. Therefore, a further study may be necessary to evaluate the flower reactions of all cultivars, too.

Two strains of E. amylovora were chosen to screen raspberry and blackberry cultivars for fire blight resistance to determine whether cultivar $\times$ strain interactions exist. Strain Eab14 appeared more virulent in all assessments. However, no cultivar $\times$ strain interaction was observed (Tables 5 and 6). The use of a larger number of strains may increase the probability of detecting an interaction.

Lehman (1933) and Starr et al. (1951) reported that strains of E. amylovora isolated from apple twigs could not infect raspberry canes. Contrary evidence was published by Braun and Hildebrand (2005), Evans (1996), and Ries and Otterbacher (1977) that apple

Table 3. Evaluation of the disease severities (\%) among raspberry cultivars to fire blight and resistance classes.

\begin{tabular}{lccccc}
\hline & \multicolumn{5}{c}{ Raspberry cultivars } \\
\cline { 2 - 6 } Mean & Williamette & Rubin & Aksu Red & Heritage & Royalty \\
\hline & $53.26 \pm 4.7$ a HS & $47.80 \pm 4.4 \mathrm{~b} \mathrm{~S}$ & $43.54 \pm 4.2 \mathrm{c} \mathrm{S}$ & $40.77 \pm 3.8 \mathrm{c} \mathrm{S}$ & $22.91 \pm 3.1 \mathrm{~d} \mathrm{MR}$
\end{tabular}

HS = highly susceptible; $\mathrm{S}=$ susceptible; $\mathrm{MR}=$ moderately resistant.

The average values in a line followed by different letters are significantly different at $P<0.01$ according to the Duncan's Multiple Range Test. $\mathrm{N}=12$, least significant difference $=3.854(P<0.01)$.

Table 4. Evaluation of the disease severities (\%) among blackberry cultivars to fire blight and resistance classes.

\begin{tabular}{cccccc}
\hline & \multicolumn{5}{c}{ Blackberry cultivars } \\
\cline { 2 - 6 } Mean & Bursa 1 & Bursa 2 & Chester & Loch Ness & Jumbo \\
\hline & $55.74 \pm 5.8$ a HS & $43.90 \pm 4.7$ b S & $39.27 \pm 4.7$ c S & $32.08 \pm 2.5 \mathrm{~d} \mathrm{~S}$ & $30.63 \pm 2.1 \mathrm{~d} \mathrm{~S}$ \\
\hline
\end{tabular}

$\mathrm{HS}=$ highly susceptible; $\mathrm{S}=$ susceptible; $\mathrm{MR}=$ moderately resistant.

The average values in a line followed by different letters are significantly different at $P<0.01$ according to the Duncan's Multiple Range Test. $\mathrm{N}=12$, least significant difference $=3.521(P<0.01)$.
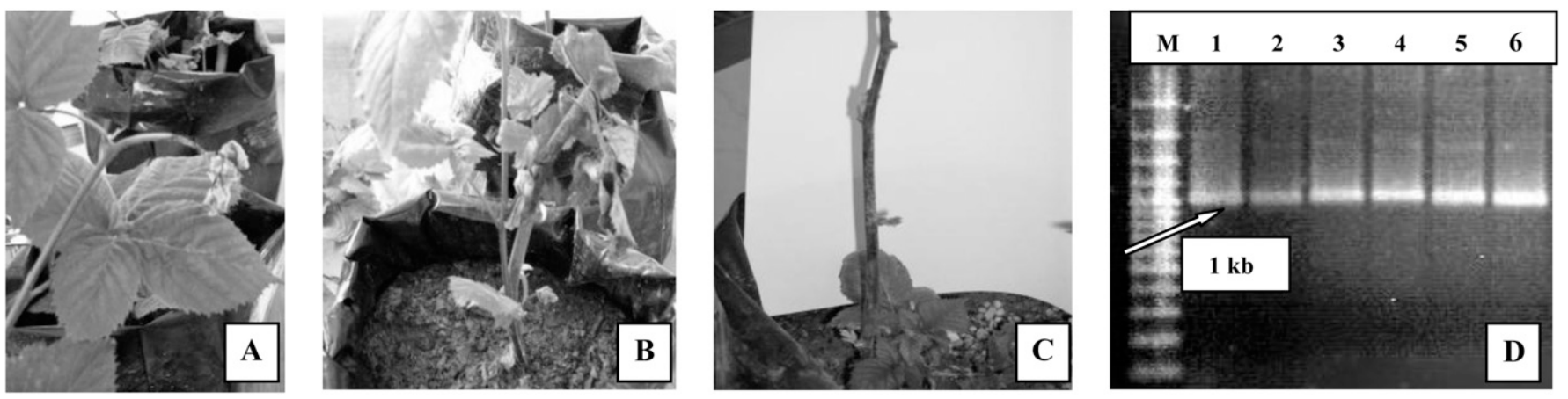

Fig. 3. Fire blight symptoms on blackberry and raspberry after bacterial inoculations in different days and polymerase chain reaction (PCR) results of re-isolated Erwinia amylovora from the plants. (A) Shoot blight symptom $7 \mathrm{~d}$ later after inoculation on blackberry cv. Chester; (B) blighting of stem after shoot $20 \mathrm{~d}$ later on blackberry cv. Bursa-1; (C) whole stem blighting at the 30th d on raspberry cv. Williamette, (D) obtained 1-kb DNA fragments of the pathogen re-isolated from blackberry and raspberry cultivars using $E$. amylovora specific primer set $(\mathrm{A} / \mathrm{B})$ by PCR assay on agarose gel $(1 \%)$. Lines: $1=$ marker; $2=$ cv. Wiliamette; $3=\mathrm{cv}$. Aksu Red; $4=$ E. amylovora strain NCPPB 2791; $5=\mathrm{cv}$. Bursa-2; $6=\mathrm{cv}$. Chester. 
Table 5. Evaluation of the disease severities (\%) among Erwinia amylovora strains and greenhouse and field to fire blight for the raspberry cultivars.

\begin{tabular}{cccccc}
\hline & \multicolumn{2}{c}{ Environment $^{2}$} & & \multicolumn{2}{c}{ Erwinia amylovora strain } \\
\cline { 2 - 3 } \cline { 5 - 6 } Mean & Greenhouse & Field & & EaK & Eab14 \\
\hline & $43.74 \pm 11.6 \mathrm{a}$ & $39.58 \pm 10.2 \mathrm{~b}$ & & $40.51 \pm 10.7 \mathrm{~b}$ & $42.80 \pm 11.5 \mathrm{a}$ \\
\hline
\end{tabular}

${ }^{\mathrm{z}}$ Statistical differences were determined at $P<0.01$ level on greenhouse or field conditions and at $P<0.05$ level on E. amylovora strains.

The average values in a line followed by different letters are significantly different at $P<0.05$ according to the Duncan's Multiple Range Test.

Table 6. Evaluation of the disease severities (\%) among Erwinia amylovora strains and greenhouse and field to fire blight for the blackberry cultivars.

\begin{tabular}{cccccc}
\hline & \multicolumn{2}{c}{ Environment $^{2}$} & & \multicolumn{2}{c}{ Erwinia amylovora strain } \\
\cline { 2 - 3 } \cline { 5 - 6 } Mean & Greenhouse & Field & & EapK & Eab14 \\
\hline & $42.57 \pm 10.9 \mathrm{a}$ & $38.07 \pm 8.6 \mathrm{~b}$ & & $38.84 \pm 9.3 \mathrm{~b}$ & $41.80 \pm 10.6 \mathrm{a}$ \\
\hline
\end{tabular}

${ }^{\mathrm{z}}$ Statistical differences were determined at $P<0.01$ level on greenhouse or field conditions and at $P<0.05$ level on E. amylovora strains.

The average values in a line followed by different letters are significantly different at $P<0.05$ according to the Duncan's Multiple Range Test.

Existence of resistance to E. amylovora among the blackberry and raspberry cultivars grown in Turkey was determined in this study. Disease index and disease severity data classified raspberry and blackberry cultivars into four groups based on their resistance to fire blight disease in greenhouse and field conditions. None of the cultivars tested was highly resistant, but one of the raspberry cv. Royalty was moderately resistant to fire blight. It was also the most resistant raspberry tested in Braun et al. (2004). This variety is actually of a distinct species background, and maybe black raspberry ( $R$. occidentalis) should be examined as a resistance source. Raspberry cv. Willamette and blackberry cv. Bursa I were highly susceptible, and all the other remaining cultivars were found to be susceptible to fire blight in this study. This is the first study of determination of resistance in blackberries and raspberries cultivars against fire blight in Turkey. As the cultivation of berries expands to new regions and larger acreages, a serious outbreak of fire blight may be potentially much more destructive in the future. Therefore, phytosanitary measures are needed to prevent any further spread of the bacterium to new blackberry- and raspberry-growing areas. The study will serve as an initial guide for growers and breeders for their appropriate raspberry and blackberry selections in Turkey.

\section{Literature Cited}

Agaoglu, Y.S. 2003. Past, present and future of small fruits in Turkey. I. National Kiwifruit and Small Fruits Symposium, Ordu. p. 1-13.

Ahn, D., D. Putt, L. Kresty, G.D. Stoner, D. Fromm, and P.F. Hollenberg. 1996. The effects of dietary ellagic acid on rat hepatic and esophageal mucosal cytochromes P450 and phase II enzymes. Carcinogenesis 17:821828.

Aldwinckle, H., R.M.V. Bhaskara, and J. Norelli. 2002. Evaluation of control of fire blight infection of apple blossoms and shoots with SAR inducers, biological agents, a growth regulator, copper compounds and other materials. Acta Hort. 590:325-331.

Barut, E. 2000. Raspberry growing in Turkey. Small Fruits Rev. 1:57-61.
Bastas, K.K. and F. Sahin. 2012. First report of fire blight disease on blackberry in Turkey. Plant Dis. 96:1818.

Beer, S.V. 1990. Fire blight, p. 61-63. In: Jones, A.L. and H.S. Aldwinckle (eds.). Compendium of apple and pear diseases. American Phytopathological Society Press, St. Paul, MN.

Bereswill, S., A. Pahl, P. Bellemann, W. Zeller, and K. Geider. 1992. Sensitive and species-specific detection of Erwinia amylovora by polymerase chain reaction analysis. Appl. Environ. Microbiol. 58:3522-3526.

Bonn, W.G. and T. van der Zwet. 2000. Distribution and economic importance of fire blight, $\mathrm{p}$. 37-53. In: Vanneste, J.L. (ed.). Fire blight: The disease and its causative agent, Erwinia amylovora. CABI Publishing, Cambridge, MA.

Braun, P.G. and P.D. Hildebrand. 2005. Infection, carbohydrate utilization and protein profiles of apple, pear and raspberry isolates of Erwinia amylovora. Can. J. Plant Pathol. 27:338-346.

Braun, P.G. and P.D. Hildebrand. 2006. Epidemiology of fire blight of floricane fruiting red raspberry caused by Erwinia amylovora. Can. J. Plant Pathol. 28:95-99.

Braun, P.G., P.D. Hildebrand, and A.R. Jamieson. 1999. Screening raspberries for resistance to fire blight (Erwinia amylovora). Acta Hort. 505:369-372.

Braun, P.G., P.D. Hildebrand, and A.R. Jamieson. 2004. Resistance of raspberry cultivars to fire blight. HortScience 39:1189-1192.

Carvalho, E., P.D. Fraser, and S. Martens. 2013. Carotenoids and tocopherols in yellow and red raspberries. Food Chem. 139:744-752.

Crosse, J.E. and R.N. Goodman. 1973. A selective medium for and a definitive colony characteristic of E. amylovora. Phytopathology 63:14251426.

Duzgunes, O., T. Kesici, O. Kavuncu, and F. Gurbuz. 1987. Statistical methods-II. Agriculture faculty publishes 1021, lesson book. Ankara University Press, Ankara, Turkey.

Evans, I.R. 1996. Fire blight of raspberries in Alberta. Acta Hort. 411:69-72.

Fernando, W.G.D. and A.L. Jones. 1999. Prohexadione-Ca: A tool for reducing secondary fire blight infections. Acta Hort. 489:597-600.

Folsom, D. 1947. Bacterial twig and blossom blight of raspberry in Maine. Plant Dis. Rpt. 31:324.

Heimann, M.F. and S.N. Jeffers. 1990. Raspberry disorder: Fire blight. Univ. Wisc.-USDA Ext. Urban Phytonarian Ser. Bul. A3499.

Heinonen, M. 2007. Antioxidant activity and antimicrobial effect of berry phenolics: A Finnish perspective. Mol. Nutr. Food Res. 51:684-691.
Ipek, A., E. Barut, H. Gulen, and M. Ipek. 2009. Genetic diversity among some blackberry cultivars and their relationship with boysenberry assessed by AFLP Markers. Afr. J. Biotechnol. 8:4830-4834.

Jeng, R.S., A.M. Svircev, A.L. Myers, L. Beliaeva, D.M. Hunter, and M. Hubbes. 2001. The use of $16 \mathrm{~S}$ and $16 \mathrm{~S}-23 \mathrm{~S}$ rDNA to easily detect and differentiate common Gram-negative orchard epiphytes. J. Microbiol. Methods 44: 69-77.

Kacar, B. and V. Katkat. 1999. Fertilizers and techniques of fertilizing. Vipas Press, Bursa, Turkey.

Kado, C.I. and M.G. Heskett. 1970. Selective media for isolation of Agrobacterium, Corynebacterium, Pseudomonas, and Xanthomonas. Phytopathology 60:969-976.

Kim, J.H. and S.V. Beer. 1996. Characterization of Erwinia amylovora strains from different hosts and geographical areas. Acta Hort. 411:183185.

Kim, J.H., S.V. Beer, A. Tanii, C.H. Zumoff, R.J. Laby, H.L. Gustafson, and H.S. Aldwinckle. 1996. Characterization of Erwinia amylovora strains from different hosts and geographical areas. Acta Hort. 411:183-186.

Klement, Z., K. Rudolph, and D.C. Sands. 1990. Methods in phytobacteriology. Akademia Kiado, Budapest, Hungary.

Lehman, S. 1933. Bacterial twig and blossom blight of raspberry. Phytopathology 23:21 (abst.).

Lelliott, R.A. and D.E. Stead. 1987. Methods for the diagnosis of bacterial diseases of plants. Blackwell Scientific Publications.

Llop, P., P. Caruso, J. Cubero, C. Morente, and M.M. Lopez. 1999. A simple extraction procedure for efficient routine detection of pathogenic bacteria in plant material by polymerase chain reaction. J. Microbiol. Methods 37:2331.

Maes, M., K. Orye, S. Bobev, B. Devreese, J. Van Beeumen, A. De Bruyn, R. Busson, P. Herdewijn, K. Morreel, and E. Messens. 2001. Influence of amylovoran production on virulence of Erwinia amylovora and a different amylovoran structure in E. amylovora isolates from Rubus. Eur. J. Plant Pathol. 107: 839-844.

McManus, P.S. and A.L. Jones. 1995. Genetic fingerprinting of Erwinia amylovora strains isolated from tree-fruit crops and Rubus spp. Phytopathology 85:1547-1553.

Momol, M.T., E.A. Momol, W.F. Lamboy, J.L. Norelli, S.V. Beer, and H.S. Aldwinkle. 1997. Characterization of Erwinia amylovora strains using random amplified polymorphic DNA fragments (RAPDs). J. Appl. Microbiol. 82:389-398.

MSU. 1986. MSTATC Version 4.00. East Lansing, MI.

Nissinen, R.M., K.J. Van Wijk, J.A. Ytterberg, T. Thannhauser, and S.V. Beer. 2002. Weaponry revealed: Secreted proteins of E. amylovora. Phytopathology 92:59 (abst.).

Norelli, J.L., H.S. Aldwinckle, and S.V. Beer. 1984. Differential host x pathogen interactions among cultivars of apple and strains of $E$. amylovora. Phytopathology 74:136-139.

Onur, C. 1996. Raspberry growing. Citrus and Greenhouse Research Institute, Antalya, Turkey.

Ries, S.M. 1997. Fire blight, p. 40-41. In: Ellis, M.A., R.H. Converse, R.N. Williams, and B. Williamson (eds.). Compendium of raspberry and blackberry diseases and insects. American Phytopathological Society Press, St. Paul, MN. 
Ries, S.M. and A.G. Otterbacher. 1977. Occurrence of fire blight on thornless blackberry in Illinois. Plant Dis. Rptr. 61:232-235.

Schaad, N.W., J.B. Jones, and W. Chun. 2001. Laboratory guide for identification of plant pathogenic bacteria. 3rd Ed. American Phytopathological Society Press, St. Paul, MN.

Schilder, A. 2007. Fire blight on raspberries and blackberries. 2014. <http://www.msue.anr $\mathrm{msu}$.edu/news/fire-blight-on-raspberries-andblackberries $>$.
Sellappan, S., C.C. Akoh, and G. Krewer. 2002. Phenolic compounds and antioxidant capacity of Georgia-grown blueberries and blackberries. J. Agr. Food Chem. 50:24322438.

Starr, M.P., C. Cardona, and D. Folsom. 1951. Bacterial fire blight of raspberry. Phytopathology 41:914-919.

Stewart, P.J., J.R. Clark, and P. Fenn. 2005. Sources and inheritance of resistance to fire blight (E. amylovora) in eastern U.S. blackberry genotypes. HortScience 40:39-42.
Van der Zwet, T. and H.L. Keil. 1979. Fire blight: A bacterial disease of rosaceous plants: U.S. Dept. Agr. Agr. Hdbk. No. 510.

Zeller, W. and J. Meyer. 1975. Studies on fireblight in the German Federal Republic. I. Disease development on fruit trees and ornamental plants after natural attack and artificial inoculation. Nachrich. des Deut. Pflanzens. 27:161-169.

Zhang, X. and K. Geider. 1997. Differentiation of Erwinia amylovora strains by pulsed-field gel electrophoresis. Appl. Environ. Microbiol. 63:4421-4426. 